\title{
Hallux amputation after a freshwater stingray injury in the Brazilian Amazon
}

\author{
Wuelton Marcelo Monteiro[1],[2], Sâmella Silva de Oliveira ${ }^{[1],[2],}$ \\ Jacqueline de Almeida Gonçalves Sachett ${ }^{[1],[2], ~ I r a n ~ M e n d o n c ̧ a ~ d a ~ S i l v a ~}{ }^{[1],[2],}$ \\ Luiz Carlos de Lima Ferreira ${ }^{[1],[2]}$ and Marcus Vinícius Guimarães Lacerda ${ }^{[1],[2],[3]}$
}

\begin{abstract}
[1]. Diretoria de Ensino e Pesquisa, Fundação de Medicina Tropical Dr. Heitor Vieira Dourado, Manaus, Amazonas, Brasil. [2]. Escola Superior de Ciências da Saúde, Universidade do Estado do Amazonas, Manaus, Amazonas, Brasil.

[3]. Instituto de Pesquisa Leônidas \& Maria Deane, Fundação Oswaldo Cruz, Manaus, Amazonas, Brasil.
\end{abstract}

\begin{abstract}
Freshwater stingray injuries are a common problem in the Brazilian Amazon, affecting mostly riverine and indigenous populations. These injuries cause severe local and regional pain, swelling and erythema, as well as complications, such as local necrosis and bacterial infection. Herein, we report a case of bacterial infection and hallux necrosis, after a freshwater stingray injury in the Brazilian Amazon, which eventually required amputation. Different antimicrobial regimens were administered at different stages of the disease; however, avoiding amputation through effective treatment was not achieved.
\end{abstract}

Keywords: Stingray envenomation. Bacterial infection. Necrosis.

\section{INTRODUCTION}

According to the Brazilian official surveillance system, out of all reported injuries from aquatic animals in the Brazilian Amazon, those from freshwater stingrays are most common $(88.4 \%)^{(1)}$. These envenomings are most likely unreported, as it is difficult for riverine and indigenous populations living in remote areas to reach health centers for treatment of venomous animal injuries. Moreover, delays in patient care, along with the use of folk medicines may damage the wound site and often lead to local complications ${ }^{(2)}$. An epidemiological survey from Acre State, Brazil, found that stingray injuries were common accidents, with $18 \%$ of rubber tappers and $23 \%$ of Amerindians affected at least once in their lifetime ${ }^{(3)}$. Thus, it is important to assess disease burden through population- and hospital-based field studies in remote localities in order to understand the extent of complications and disabilities following those neglected injuries.

In the Brazilian Amazon, the main recorded species of freshwater stingrays bearing venomous barbs are Paratrygon aiereba, Potamotrygon orbignyi, and Potamotrygon motoro, which can be found in the Amazonas, Tocantins, and Negro river basins. The cururu stingrays (Potamotrygon sp.) and Potamotrygon schroederi are endemic in the Rio Negro

Corresponding author: Dr. Wuelton Marcelo Monteiro.

e-mail:wueltonmm@gmail.com

Received 29 September 2015

Accepted 27 January 2016 $\operatorname{basin}^{(4)}$. The stingray's venom has necrotizing, edematous, proteolytic, neurotoxic and myotoxic effects ${ }^{(5)}\left({ }^{()}\right.$. Stingray injuries immediately cause severe local signs and symptoms of immense pain and swelling ${ }^{(2)}(7)$, and often lead to necrosis and secondary infections ${ }^{(7)}$. Here, we report a case of bacterial infection and hallux necrosis eventually requiring amputation after a freshwater stingray injury in the Brazilian Amazon.

\section{CASE REPORT}

We describe a case of bacterial infection requiring hallux amputation after a freshwater stingray injury in a 43-year-old man born and living in Ariquemes (Rondônia State, Brazil). Anamnesis of the patient showed absence of smoking, alcohol abuse, illicit drug use, diabetes, previous surgery, blood transfusion, and drug allergy. Information about his vaccination status was lacking. The patient suffered from systemic arterial hypertension for 5 years, for which he received no treatment; 3 years ago, he was diagnosed as a hepatitis B virus carrier.

The patient reported that he had been bathing and walking in the margins of the Canaã River in Ariquemes, when a stingray struck him in the dorsal area of his right foot. The patient described an immediate onset of intense local pain, radiating to his ipsilateral lower limb. He was seen at the local public hospital where analgesic medication and ceftriaxone ( $2 \mathrm{~g} /$ day) were prescribed. All laboratorial tests during his medical assistance are presented in Table 1. He had normal blood counts, with a leukocyte count of 6,000 cells $/ \mathrm{mm}^{3}$ (70\% neutrophils; $28 \%$ lymphocytes) and hemoglobin $12.7 \mathrm{~g} / \mathrm{dL}$; normal activated clotting time $\left(6^{\prime}\right)$, and prothrombin activity of $79 \%$. The patient remained 
TABLE 1 - Laboratorial results by day of hospitalization.

\begin{tabular}{|c|c|c|c|c|}
\hline Parameter & Day 1 & Day 9 & Day 12 & Day 18 \\
\hline $\mathrm{WBC} / \mathrm{mL}$ & 6,000 & 6,600 & 9,300 & 11,700 \\
\hline Lymphocytes (\%) & 28 & 22.6 & 18.7 & 22 \\
\hline Neutrophils (\%) & 70 & 70.2 & 71.7 & 69 \\
\hline Eosinophils (\%) & 1 & - & 3.7 & 5 \\
\hline Hematocrit (\%) & 38 & - & 37.6 & 34.5 \\
\hline Hemoglobin (g/dL) & 12.7 & 12.6 & 12.5 & 12.3 \\
\hline Platelets $/ \mathrm{mm}^{3}$ & - & 275,000 & 403,000 & 511,000 \\
\hline AST (U/L) & - & - & 175 & 130 \\
\hline $\mathrm{Na}^{+}(\mathrm{mEq} / \mathrm{L})$ & - & - & 143 & 141 \\
\hline $\mathrm{K}^{+}(\mathrm{mEq} / \mathrm{L})$ & - & - & 3.5 & 4.7 \\
\hline Urea $(\mathrm{mg} / \mathrm{dL})$ & - & - & 52 & 46 \\
\hline Creatinine (mg/dL) & - & - & 1.1 & 1.1 \\
\hline
\end{tabular}

WBC: white blood cells; RBC: red blood cells; PAP: prothrombin activity percentage; ALT: alanine aminotransferase; AST: aspartate aminotransferase. Reference ranges: WBC: 5,000-10,000/mL; lymphocytes: 16-45\%; neutrophils: 45-74\%; eosinophils: 0-7\%; monocytes: 4-10\%; RBC: 4.6-6.2 million/ $\mathrm{mL}$; hematocrit: $37-47 \%$; hemoglobin: $12-16 \mathrm{~g} / \mathrm{dL}$; platelets: 150,000-450,000/mm³; clotting time: 2-12 min; PAP: 70-100\%; AST: 10-40U/L; ALT: 7-56U/L; $\mathrm{Na}^{+}: 136-145 \mathrm{mEq} / \mathrm{L} ; \mathrm{K}^{+}: 3.6-5.2 \mathrm{mEq} / \mathrm{L}$; urea: $15-40 \mathrm{mg} / \mathrm{dL}$; creatinine: $0.4-1.3 \mathrm{mg} / \mathrm{dL}$.

in severe pain with burning sensations, suffered from erythema and edema, and his right hallux developed necrosis on the fourth day; intravenous administration of clindamycin $(600 \mathrm{mg} /$ $\mathrm{kg} /$ day) was added to the initial regimen of antimicrobials.

On the ninth day, the patient received surgical wound debridement and was subsequently referred to the reference center for tropical diseases in Manaus, Amazonas State. On admission, the patient had no complaints; his physical exam showed normal findings, except for mild right foot edema and a necrotic hallux that was painful on palpation, with darkened lesions in its dorsal region (Figure 1). Fever was absent throughout the course of his admission. Blood tests showed a leukocyte count of 6,600 cells $/ \mathrm{mm}^{3}$ (71\% neutrophils; $23 \%$ lymphocytes), platelet count of $275,000 / \mathrm{mm}^{3}$, and hemoglobin level of $12.6 \mathrm{~g} / \mathrm{dL}$. The patient continued receiving clindamycin.

On day 12 after the accident, the leukocyte count was 9,300 cells $/ \mathrm{mm}^{3}$ (72\% neutrophils; 19\% lymphocytes), platelet count $403,000 / \mathrm{mm}^{3}$, hemoglobin level $12.5 \mathrm{~g} / \mathrm{dL}$, prothrombin activity $79 \%$, alanine transaminase level $175 \mathrm{U} / \mathrm{L}$, and aspartate transaminase level $54 \mathrm{U} / \mathrm{L}$. The serum levels of urea were mildly elevated $(52 \mathrm{mg} / \mathrm{dL})$, but the creatinine $(1.1 \mathrm{mg} / \mathrm{dL})$, $\mathrm{Na}^{+}(143 \mathrm{mmol} / \mathrm{L})$ and $\mathrm{K}^{+}(3.5 \mathrm{mmol} / \mathrm{L})$ levels were normal. Intravenous oxacillin $(500 \mathrm{mg} / \mathrm{kg} / \mathrm{day})$ was added to the antimicrobial regimen.
On day 18 , the leukocyte count was 11,700 cells $/ \mathrm{mm}^{3}(69 \%$ neutrophils; $22 \%$ lymphocytes), platelet count $511,000 / \mathrm{mm}^{3}$, hemoglobin level $12.3 \mathrm{~g} / \mathrm{dL}$, alanine transaminase level 130U/L, and aspartate transaminase levels 32U/L. Serum level of urea continued to be mildly elevated $(46 \mathrm{mg} / \mathrm{dL})$, and creatinine $(1.1 \mathrm{mg} / \mathrm{dL}), \mathrm{Na}^{+}$ $(141 \mathrm{mmol} / \mathrm{L})$, and $\mathrm{K}^{+}(4.7 \mathrm{mmol} / \mathrm{L})$ remained normal.

That same day, the patient experienced dry necrosis of the distal phalanx of the right hallux requiring amputation (Figure 1). Antibiotics were continued for 7 more days and the patient recovered well.

\section{Ethical considerations}

This patient was enrolled in a study approved by the Ethics Review Board of the Fundação de Medicina Tropical Dr. Heitor Vieira Dourado, with a waiver of informed consent (approval number 713.140/2014).

\section{DISCUSSION}

Acute manifestations of stingray injuries are extremely disabling, require about 3 months to heal, and affect mainly the poor in deprived rural areas. This highlights the importance of more awareness for prevention of this neglected envenomation, as health facilities in these rural areas are often lacking. The prevalence of concurrent bacterial infections in such injuries 


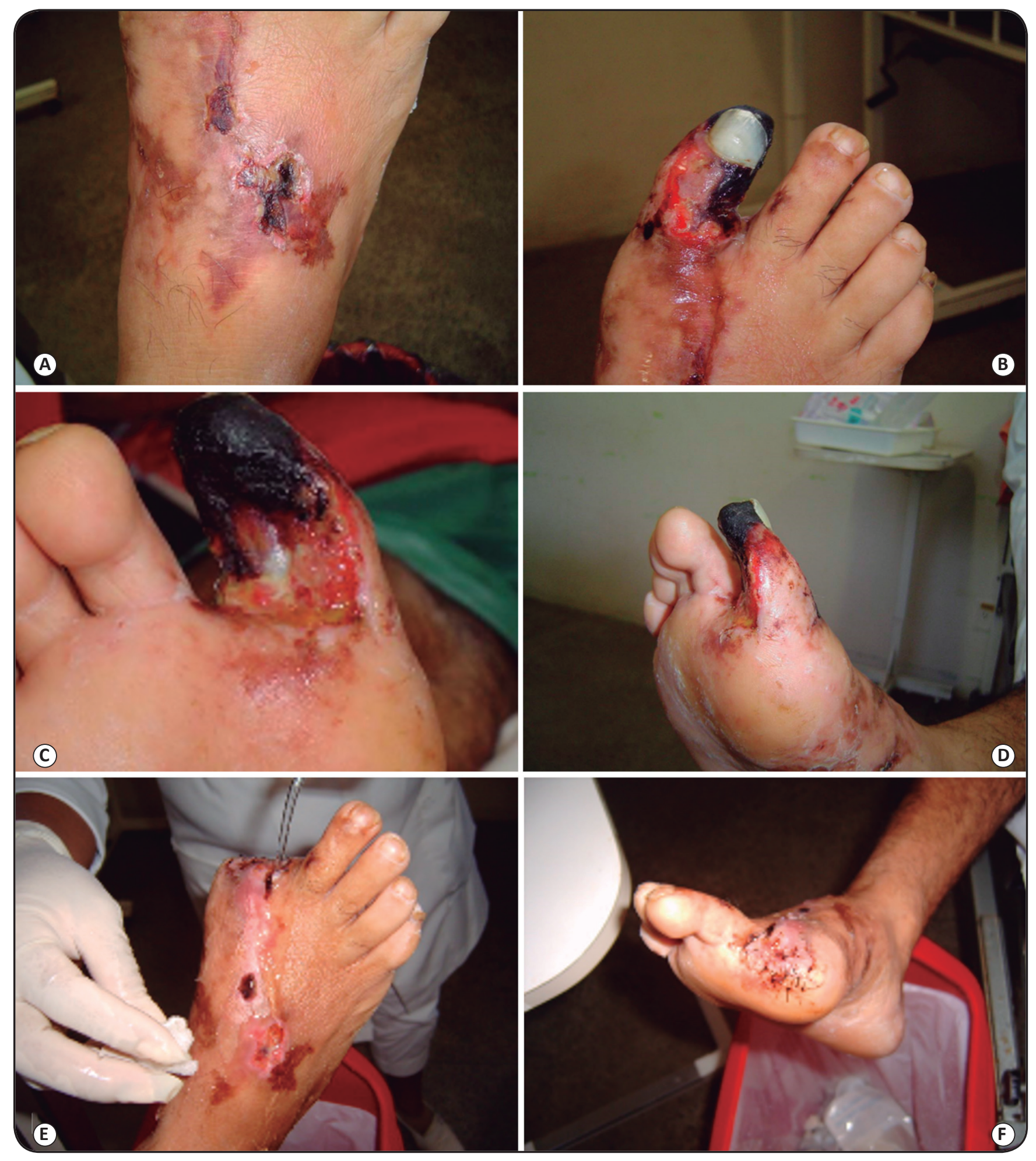

FIGURE 1 - Local complications resulting from a freshwater stingray injury. A. Darkened lesions in dorsal region of the right foot, 9 days after the accident at admission to the reference center for tropical diseases in Manaus, Amazonas State. B., C. and D. Right foot edema and necrotic hallux, also on day 9. E. and F. After amputation of the right hallux, 18 days after the freshwater stingray injury. 
is unknown ${ }^{(2)}$. In this case report, the victim survived with permanent physical sequelae due to local tissue necrosis and secondary infection. Another case report describes a patient in Central Brazil whose wound closed around 70 days after the stingray injury; however, the patient continued to have problems wearing shoes even 8 months later ${ }^{(8)}$. Necrotizing fasciitis secondary to stingray injuries has also been reported in other countries ${ }^{(9)}$. Because most victims are young adults, the economic impact of stingray injuries can be considerable ${ }^{(1)(7)}$.

In Brazil, although stingray injuries have been associated with bacterial infection and necrosis, limited information was available about the frequency of these complications. Skin necrosis estimates ranged from $33.5 \%$ of all stingray injuries in the Pará State ${ }^{(7)}$ to more than $90 \%$ in Tocantins, Mato Grosso do Sul, Paraná and São Paulo States ${ }^{(10)}$. Secondary infection was recorded in $28.6 \%$ of injured patients in the Amazon ${ }^{(7)}$. Small sample sizes and the lack of a standardized clinical protocol that includes a definition for secondary infections impede the calculation of a precise estimate for these outcomes.

The recommended therapeutic approach consists of analgesics and anti-inflammatory drugs, immersion of the injured body part in hot water for pain relief and, in light of the high risk for bacterial contamination in the punctured wounds, antibiotic prophylaxis may be prudent ${ }^{(11)}$. The most common agents in Potamotrygon motoro stingray mucus are gram-negative rods, namely Aeromonas spp., including B-lactam-resistant bacterial strains with the potential to cause severe secondary infection in stingray-acquired wounds ${ }^{(12)}$. In the present case, different antimicrobial regimens were employed throughout the different clinical stages of the case. Treatment failure for ciprofloxacin was previously reported in a patient in Central Brazil presenting with a stingray wound infection ${ }^{(8)}$. Therefore, the treatment failure in this patient may have been due to the presence of ceftriaxone-resistant bacterial strains. A contiguous action of the venom may also have been the cause of the large extent of the necrosis in this patient, possibly complicated by peripheral vasculitis due to his chronic $\mathrm{B}$ hepatitis infection. It is difficult to assess the causality of bacterial infections, considering that skin contamination may impair the interpretation of swabs collected from this area. This emphasizes the unusual clinical presentation of our case and highlights the need for a more detailed clinical and histopathological analysis in future patients.

Medical management of secondary infection, abscess, and necrosis from stingray injuries has been a subject of controversy, partly because standardization of concepts and management protocols, as well as medical training is lacking ${ }^{(8)}$. In future cases, a more aggressive surgical approach is recommended. Further investigations, whilst safeguarding good clinical practice, should assess whether early antibiotic therapy for secondary infection, drugs with anti-inflammatory activity and complementary treatments reduce local effects and sequelae. Cooperative efforts through research and surveillance partnerships to control these neglected health problems in the Amazon region are imperative.

\section{Acknowledgments}

We thank the clinical and laboratorial staff of the Fundação de Medicina Tropical Dr. Heitor Vieira Dourado.

\section{Conflict of interest}

The authors declare that there is no conflict of interest.

\section{Financial Support}

This work was funded by the Amazonas Research Foundation [Fundação de Amparo à Pesquisa do Estado do Amazonas (FAPEAM)-Programa Pesquisa para o Sistema Único de Saúde (PPSUS) no. 1094/2013] and the Agency for the Support and Evalution of Graduate Education [Coordenação de Aperfeiçoamento de Pessoal de Nivel Superior (CAPES)]- Programa Nacional de Cooperação Acadêmica (PROCAD) no. 2992/0201). MVGL is a level 1 fellow from the National Counsel of Technological and Scientific Development (Conselho Nacional de Desenvolvimento Cientifico e Tecnológico; CNPq). The funders had no role in the study design, data collection and analysis, decision to publish, or preparation of the manuscript.

\section{REFERENCES}

1. Reckziegel GC, Dourado FS, Garrone Neto D, Haddad Jr V. Injuries caused by aquatic animals in Brazil: an analysis of the data present in the information system for notifi able diseases. Rev Soc Bras Med Trop 2015; 48:460-467.

2. Haddad Jr V, Cardoso JLC, Garrone Neto D. Injuries by marine and freshwater stingrays: history, clinical aspects of the envenomations and current status of a neglected problem in Brazil. J Venom Anim Toxins Incl Trop Dis 2013; 19:16.

3. Pierini S, Warrell D, Paulo D, Theakston R. High incidence of bites and stings by snakes and other animals among rubber tappers and amazonian indians of the Juruá Valley, Acre state, Brazil. Toxicon 1996; 34:225-236.

4. Rosa RS, Charvet-Almeida P, Quijada CCD. Biology of the South American Potamotrygonid stingrays. In: Carrier JC, Musick JA, Heithaus MR, editors. Sharks and their relatives II: biodiversity, adaptative physiology and conservation. $1^{\text {st }}$ edition, United States: CRC Press; 2010. p. 241-286.

5. Barbaro KC, Lira MS, Malta MB, Soares SL, Garrone Neto D, Cardoso JLC, et al. Comparative study on extracts from the tissue covering the stingers of freshwater (Potamotrygon falkneri) and marine (Dasyatis guttata) stingrays. Toxicon 2007; 50:676-687.

6. Magalhães KW, Lima C, Piran-Soares AA, Marques EE, HirumaLima CA, Lopes-Ferreira M. Biological and biochemical properties of the Brazilian Potamotrygon stingrays: Potamotrygon cf. scobina and Potamotrygon gr. orbignyi. Toxicon 2006; 47:575-583.

7. Pardal PPO. Estudo dos acidentes por arraias fluviais nas ilhas de Mosqueiro e Outeiro Distrito Belém-PA. 2002. 78 p. (Master's Dissertation). Núcleo de Medicina Tropical. Universidade Federal do Pará; 2000: Belém.

8. Da Silva Jr NJ, Ferreira KRC, Pinto RNL, Aird SD. A severe accident caused by an Ocellate River stingray (Potamotrygon motoro) in Central Brazil: how well do we really understand stingray venom chemistry, envenomation, and therapeutics? Toxins (Basel) 2015; 7:2272-2288.

9. Barber G, Swygeter J. Necrotizing fasciitis due to Photobacterium damsela in a man lashed by a stingray. N Engl J Med 2000; 342:824.

10. Garrone-Neto DG, Haddad Jr V. Stingrays in rivers in southeastern Brazil: occurrence localities and impact on the population. Rev Soc Bras Med Trop 2010; 43:82-88.

11. Clark RF, Girard RH, Rao D, Ly BT, Davis DP. Stingray envenomation: a retrospective review of clinical presentation and treatment in 119 cases. J Emerg Med. 2007; 33:33-37.

12. Domingos MO, Franzolin MR, dos Anjos MT, Franzolin TM, Barbosa-Albes RC, de Andrade GR, et al. The influence of environmental bacteria in freshwater stingray wound-healing. Toxicon 2011; 58:147-153. 